\title{
PKM Guru Pembina Olimpiade Matematika Dan IPA SD Di Wilayah Gugus I Kecamatan Banawa Selatan Kabupaten Donggala
}

\author{
Pathuddin, Linawati \\ Program studi Pendidikan Matematika FKIP Universitas Tadulako \\ Email: pathuddin@yahoo.com
}

\begin{abstract}
Abstrak. Mitra dari Program Kemitraan Masyarakat (PKM) ini adalah Kelompok Kerja Guru (KKG) SD Wilayah Gugus I. Permasalahan yang dihadapi kelompok mitra: 1). Penguasaan guru/Anggota KKG tersebut terhadap materi dan pembahasan soal-soal olimpiade matematika dan IPA masih rendah. 2) Guru SD di wilayah gugus I tersebut pada umumnya alumni D2 dan S1 PGSD, di mana mereka pada saat kuliah hanya mendapatkan materi matematika dasar dan IPA yang tingkat abstraksinya masih rendah. Hal tersebut menyebabkan guru/Anggota KKG di wilayah tersebut, masih sering salah memahami konsep-konsep dasar matematika dan IPA. 3). Selain itu referensi yang dapat dijadikan sebagai bahan pengayaan juga kurang, dan 4). Narasumber yang bisa ditempati bertanya tentang materi Olimpiade matematika dan IPA juga kurang, karena kecamatan Banawa Selatan berada di wilayah perbatasan provinsi Sulawesi Tengah dan Sulawesi Barat. Adapun tujuan dari PKM meningkatkan kemampuan guru SD dalam menyelesaian soal-soal olimpiade matematika dan IPA, agar nantinya dapat membimbing siswa yang akan ikut olmpiade tingkat kabupaten, provinsi dan nasional. Target luaran yang diharapkan dalam kegiatan PKM adalah Minimal 5 orang anggota KKG wilayah gugus I tersebut dapat mengerjakan soal-soal olimpiade tingkat kota tahun 2019, sehingga dapat membimbing siswanya untuk bisa lolos ke seleksi tingkat propinsi. Setelah kegiatan ini selesai, para peserta diharapkan dapat meneruskan pengetahuannya kepada rekan guru yang lain. Buku hasil pembahasan soal-soal olimpiade tingkat kota dan propinsi, hasil kerja anggota KKG wilayah tersebut untuk dijadikan salah satu referensi kedepan. Untuk mencapai target tersebut, metode yang digunakan dalam kegiatan PKM ini adalah pemberian pelatihan tentang materi dan pembahasan soal-soal olimpiade matematika dan IPA, konsep-konsep dasar matematika dan IPA yang penting dan menunjang untuk mengikuti materi matematika dan IPA yang membutuhkan analisa lebih tinggi. Melakukan pendampingan untuk memastikan materi yang disampaikan kepada mitra dapat dilaksanakan dengan baik sehingga hasil yang diperoleh dapat mencapai sasaran.
\end{abstract}

Kata Kunci: Olimpiade; Matematika dan IPA; Pelatihan; Pendampingan; Soal

Abstract. Partners of the Community Partnership Program (PKM) are the SD Teachers Working Group (KKG) Cluster I Region. Problems faced by partner groups: 1). The mastery of the teachers / KKG members on the material and discussion of math and science Olympiad questions is still low. 2) The elementary school teachers in the cluster I areas were generally D2 and S1 PGSD alumni, where at the time they were studying only basic mathematics and science material, which had a low level of abstraction. This causes teachers / KKG members in the region to often misunderstand the basic concepts of mathematics and science. 3). In addition, references that can be used as enrichment materials are also lacking, and 4). Available sources to ask questions about the mathematics and science Olympiad material are also lacking, because the South Banawa sub-district is located in the border area of the provinces of Central Sulawesi and West Sulawesi. The goal of PKM is to improve the ability of elementary school teachers to solve math and science Olympiad questions, so that later they can guide students who will take part in the district, provincial and national level Olympiad. The expected output target in PKM activities is that at least 5 KKG members in the cluster I region can work on the 2019 city level Olympic questions, so that they can guide their students to qualify for the provincial level selection. After this activity is completed, the participants are expected to be able to pass on their knowledge to other fellow teachers. The book is the result of discussion of Olympic questions at the city and provincial levels, the work of the regional KKG members to be used as one of the future references. To achieve this target, the method used in this PKM activity is to provide training on material and discussion of mathematics and science Olympiad questions, basic concepts of mathematics and science which are important and support for following mathematics and science materials which require higher analysis. Provide assistance to ensure the material presented to partners can be implemented properly so that the results obtained can reach the target.

Keywords: Olympics; Mathematics and Science; Training; Accompaniment; Question 


\section{PENDAHULUAN}

Kecamatan Banawa Selatan terdiri dari 34 sekolah negeri dan 9 sekolah swasta, dengan 201 guru yang terdiri dari 55 laki-laki dan 146 perempuan. Dari 43 sekolah ini dibagi lagi menjadi 5 kelompok kerja guru (KKG), satu KKG terdiri dari 8-9 sekolah. KKG wilayah gugus I Kecamatan Banawa Selatan berasal dari 9 Sekolah Dasar, yakni: SDN 3 Banawa Selatan, SDN 6 Banawa Selatan, SDN 8 Banawa Selatan, SDN 12 Banawa Selatan, SDN 14 Banawa Selatan, SDN 16 Banawa Selatan, SDN 21 Banawa Selatan, SDN 25 Banawa Selatan, SDN 32 Banawa Selatan. Sedangkan KKG wilayah gugus II Kecamatan Banawa Selatan terdiri dari: SDN 1 Banawa Selatan, SDN 2 Banawa Selatan, SDN 9 Banawa Selatan, SDN 10 Banawa Selatan, SDN 11 Banawa Selatan, SDN 15 Banawa Selatan, SDN 29 Banawa Selatan, MIS Alkhairaat Pana'a, dan MIS Lino [1].

Pada umumnya guru SD di kecamatan Banawa Selatan yang mengajar pelajaran pelajaran matematika dan IPA adalah lulusan D2 dan S1 PGSD (bukan sarjana Pendidikan Matematika dan IPA), sehingga mereka sering mengalami masalah jika menyelesaikan soal- soal olimpiade tingkat kota, dan tingkat propinsi, apalagi soal-soal olimpiade tingkat nasional yang membutuhkan analisa yang tinggi. Data tersebut diperoleh dari hasil wawancara dengan ketua KKG gugus I kecamatan Banawa Selatan (Gambar 1). Hal ini berdampak pada siswa yang sangat membutuhkan bimbingan untuk persiapan seleksi olimpiade tingkat kota, propinsi dan Nasional. Kenyataan di lapangan dari tahun 2002 sampai sekarang belum ada siswa dari sekolah dasar di kecamatan Banawa Selatan yang bisa lolos seleksi ke tingkat nasional. Siswa sekolah dasar lainnya dari Sulawesi Tengah sampai sekarang hanya lolos ke tingkat nasional sebagai juara propinsi tanpa bisa masuk passangreadnya kecuali pada tahun 2016 dan pada tingkat nasional tidak bisa masuk 30 besar, data tersebut dapat dilihat pada Tabel 1 $[1,2]$. Hal ini sangat perlu penanganan sedini mungkin.

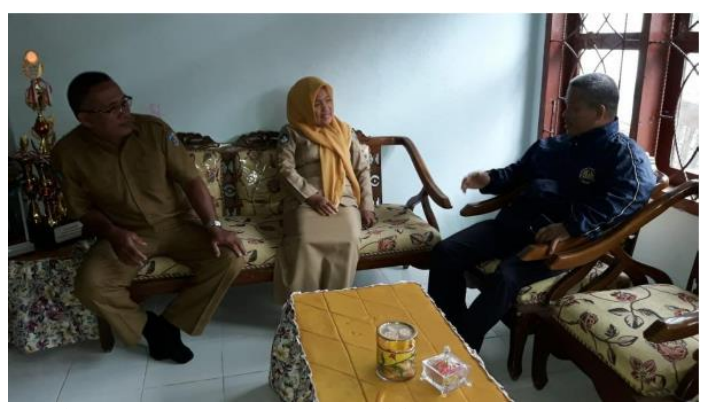

Gambar 1 Wawancara Tim peneliti dengan ketua dan sekertaris KKG gugus 1
Peningkatan mutu dan keberhasilan siswa dalam ajang olimpiade matematika secara propesional sebagian besar terletak di tangan guru. Hal menunjukkan betapa pentingnya peranan guru karena sumber terdekat tempat siswa bertanya tentang kesulitan-kesulitan dalam menyelesaikan soal-soal olimpiade di sekolah adalah guru. Kenyataannya guru sendiri sangat kesulitan untuk menyelesaikan soal olimpiade apalagi untuk mengajarkannya sama siswa. Dampak lebih jauh siswa jadi malas belajar dan mengembangkan diri serta timbul kurang percaya terhadap kemampuan gurunya. Akhirnya usaha mencerdaskan bangsa, meningkatkan kualitas pendayagunaan tenaga manusia dalam pembangunan, baik sebagai pelaku maupun sebagai obyek tujuan pembangunan dan semua usaha nasional, yang membutuhkan manusiamanusia Indonesia yang terdidik dan terlatih dengan baik dan secara operasional usaha-usaha tersebut di atas harus dimulai dari sekolah sebagai suatu lembaga pendidikan formal tidak bisa tercapai secara maksimal. Untuk meningkatkan kemampuan guru pembina olimpiade yang tergabung pada KKG SD di wilayah gugus I, maka tim pengabdi Universitas Tadulako melaksanakan suatu kegiatan pengabdian, dengan judul "PKM Guru Pembina Olimpiade Matematika dan IPA SD di Wilayah Gugus I Kecamatan Banawa Selatan Kabupaten Donggala”.

Tabel 1 Daftar peserta olimpiade sains nasional SD

\begin{tabular}{|l|l|l|l|l|l|}
\hline No & Nama & SD & Kabupaten & Provinsi & Rangking/thn \\
\hline 1 & Jovan Anthony Herman & $\begin{array}{l}\text { SD Karuna } \\
\text { Dipa }\end{array}$ & Kota Palu & $\begin{array}{l}\text { Sulawesi } \\
\text { Tengah }\end{array}$ & $\begin{array}{l}\text { Ranking } \\
\text { provinsi/2017 }\end{array}$ \\
\hline 2. & Madika Gagas Nagara & $\begin{array}{l}\text { SD Unggulan } \\
\text { Sulawesi } \\
\text { Permata } \\
\text { bangsa }\end{array}$ & Kota Palu & $\begin{array}{l}\text { Sulawesi } \\
\text { Tengah }\end{array}$ & $\begin{array}{l}\text { Ranking } \\
\text { provinsi/2018 }\end{array}$ \\
\hline 3. & $\begin{array}{l}\text { Michael Alexander } \\
\text { Angkawijaya }\end{array}$ & SD Gamaliel & Kota Palu & $\begin{array}{l}\text { Sulawesi } \\
\text { Tengah }\end{array}$ & $\begin{array}{l}\text { Ranking } \\
\text { Nasional/2016 }\end{array}$ \\
\hline 4. & Gresita Novelia Uirianto & SDN Pembina & Kab. Toli-Toli & $\begin{array}{l}\text { Sulawesi } \\
\text { Tengah }\end{array}$ & $\begin{array}{l}\text { Ranking } \\
\text { Nasional/2016 }\end{array}$ \\
\hline 5. & Mohamad Abdul Azis & $\begin{array}{l}\text { SDN 1 Laantula } \\
\text { Jaya }\end{array}$ & Kab.Morowali & $\begin{array}{l}\text { Sulawesi } \\
\text { Tengah }\end{array}$ & $\begin{array}{l}\text { Ranking } \\
\text { Nasional/2016 }\end{array}$ \\
\hline 6. & Nabil Jawad & SDN 1 Petobo & Kota Palu & $\begin{array}{l}\text { Sulawesi } \\
\text { Tengah }\end{array}$ & $\begin{array}{l}\text { Ranking } \\
\text { Nasional/2016 }\end{array}$ \\
\hline 7. & Novrani Erryztafitri & $\begin{array}{l}\text { SDN Model } \\
\text { Terpadu } \\
\text { Madani }\end{array}$ & Kota Palu & $\begin{array}{l}\text { Sulawesi } \\
\text { Tengah }\end{array}$ & $\begin{array}{l}\text { Ranking } \\
\text { Nasional/2016 }\end{array}$ \\
\hline 8. & Moh. Fadel Lahude & SDN 3 Ampana & $\begin{array}{l}\text { Kab. Tojo Una- } \\
\text { Una }\end{array}$ & $\begin{array}{l}\text { Sulawesi } \\
\text { Tengah }\end{array}$ & $\begin{array}{l}\text { Ranking } \\
\text { Provinsi/2016 }\end{array}$ \\
\hline
\end{tabular}

\section{METODE}

Metode pendekatan yang dilakukan untuk menyelesaikan permasalahan mitra adalah metode ceramah tentang pentingnya olimpiade matematika dan IPA SD sebagai bagian dari olimpiade sains dan matematika yang dilaksanakan oleh kementerian pendidikan dan kebudayaan. Pemberian pelatihan tentang materi dan pembahasan soal-soal olimpiade matematika dan IPA SD, serta pelatihan tentang konsep-konsep dasar matematika dan IPA yang penting dan sangat menunjang untuk mengikuti materi matematika dan IPA yang membutuhkan analisa yang lebih tinggi. Selanjutnya dilakukan pendampingan bagi guru- 
guru mitra menyelesaikan soal-soal olimpiade matematika dan IPA SD minimal 3 tahun terakhir, serta dibukukan sebagai contoh untuk pembahasan soal olimpiade lainnya.

\section{HASIL PELAKSANAAN PKM Pelaksanaan Kegiatan}

Program PKM KKG wilayah gugus I dilaksanakan di SDN 8 Banawa Selatan yang merupakan gugus inti untuk gugus I, dengan pertimbangan lokasinya strategis dan mudah dijangkau oleh peserta kegiatan. Kegiatan pengabdian pertama adalah telah dilakukan sosialisasi dengan pihak sekolah dan dinas (Gambar 2 ), tentang kegiatan workshop dan pelatihan yang dilaksanakan di wilayah gugus I tersebut. Rincian kegiatan workshop dan pelatihan yang dilaksanakan meliputi:

a. Peran olimpiade matematika dan IPA SD sebagai bagian dari olimpiade sains dan matematika yang dilaksanakan oleh kementerian pendidikan dan kebudayaan

b. Pelatihan tentang materi dan pembahasan soal-soal olimpiade matematika dan IPA SD.

c. Pelatihan tentang konsep-konsep dasar matematika dan IPA yang penting dan sangat menunjang untuk mengikuti materi matematika dan IPA yang membutuhkan analisa yang lebih tinggi.

d. Praktek menyelesaikan soal-soal olimpiade matematika dan IPA SD minimal 3 tahun terakhir, serta dibukukan sebagai contoh untuk pembahasan soal olimpiade lainnya.

e. Pendampingan untuk guru-guru mitra dalam menyelesaikan soal-soal olimpiade matematika dan IPA SD minimal 3 tahun terakhir.

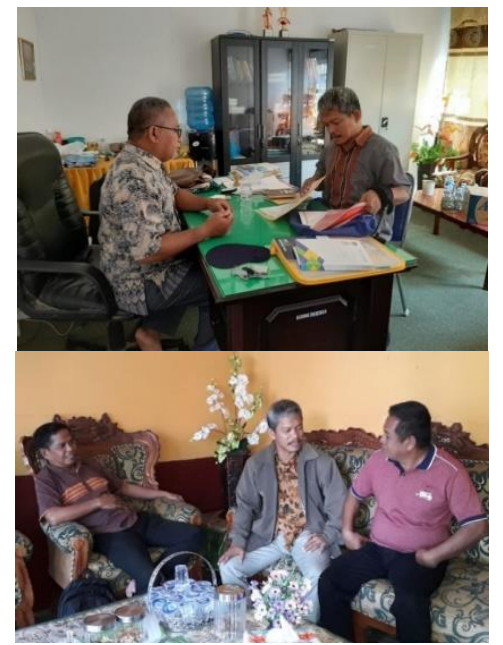

Gambar 2 Sosialisasi dengan Kepala SDN 8 Banawa Selatan dan Ketua KKG Gugus 1 wilayah kecamatan Banawa Selatan

\section{Pelaksanaan Workshop Olimpiade Matematika dan IPA SD}

Kegiatan pengabdian ini dimulai dengan sosialisasi pada mitra KKG guru SD kecamatan Banawa Selatan Kabupaten Donggala serta kepala SDN 8 Banawa Selatan. Sosialisasi ini bertujuan untuk memberi informasi kepada instansi terkait kegiatan PKM. Dalam sosialisasi tersebut juga dijelaskan tentang pentingnya olimpiade matematika dan IPA SD sebagai bagian dari olimpiade sains dan matematika yang dilaksanakan oleh kementerian pendidikan dan kebudayaan. Pelatihan dan workshop dilaksanakan di SDN 8 Banawa Selatan yang dibuka oleh kepala dinas (Gambar 3).

Materi yang disampaikan pada pelatihan (Gambar 4a-d) meliputi materi esensial yang ada di silabus olimpiade matematika dan IPA. Untuk materi matematika meliputi: Bilangan, Aritmatika Geometri, Statistika, Data, dan Pengukuran, Kombinatorik. Materi IPA sesuai juklak Direktorat Pembinaan Sekolah Dasar Direktorat Jenderal Pendidikan Dasar dan Menengah Kementerian Pendidikan dan Kebudayaan tahun 2020 [3]. Materi-materi tersebut dilatihkan untuk mencapai target luaran yaitu guru-guru mampu menyelesaikan soal-soal olimpiade, sehingga mampu membimbing/mempersiapkan siswa nya untuk berkompetisi dalam kegiatan olimpiade sains nasional.

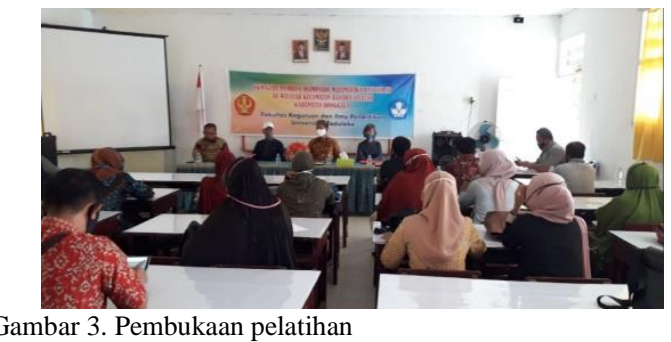

\section{Kerja Praktek Pembahasan soal-soal olimpiade matematika dan IPA SD}

Kegiatan kerja praktek pembahasan soal olimpiade matematika daan IPA SD, dilaksanakan setelah guru-guru yang tergabung dalam KKG wilayah gugus I mengikuti pendalaman materi matematika dan IPA yang esensial. Pada tahap ini, para peserta dibagi dalam kelompok, tiap kelompok dibimbing/didampingi oleh tim pengabdi, mulai dari dalam mengerjakan soal-soal olimpiade matematika SD dan IPA SD yang paling mudah sampai soal yang memerlukan analisa tinggi (Gambar 3 dan 4a). Dalam mengerjakan soal-soal olimpiade menggunakan referensi yang relevan dan lebih menekankan pada pemahaman konsep yang menjadi dasar untuk menemukan pengetahuan yang baru. Langkah-langkah tersebut sesuai dengan 
pedoman pembimbingan olimpiade dari berbagai sumber [4-10].

Semua kegiatan tersebut dilakukan secara bertahap, dimulai dari mengidentifikasi soal-soal olimpiade, mulai dengan soal-soal yang relatif lebih mudah, secara bertahap dinaikkan tingkat yang lebih sulit. Selanjutnya dalam memecahkan soal, guru-guru didampingi dan diberi petunjuk (Gambar 5) setahap demi setahap, sampai diperoleh hasil akhir yang benar [5]. Hal tersebut diharapkan dapat diterapkan pada saat membimbing siswa-siswanya di lapangan.

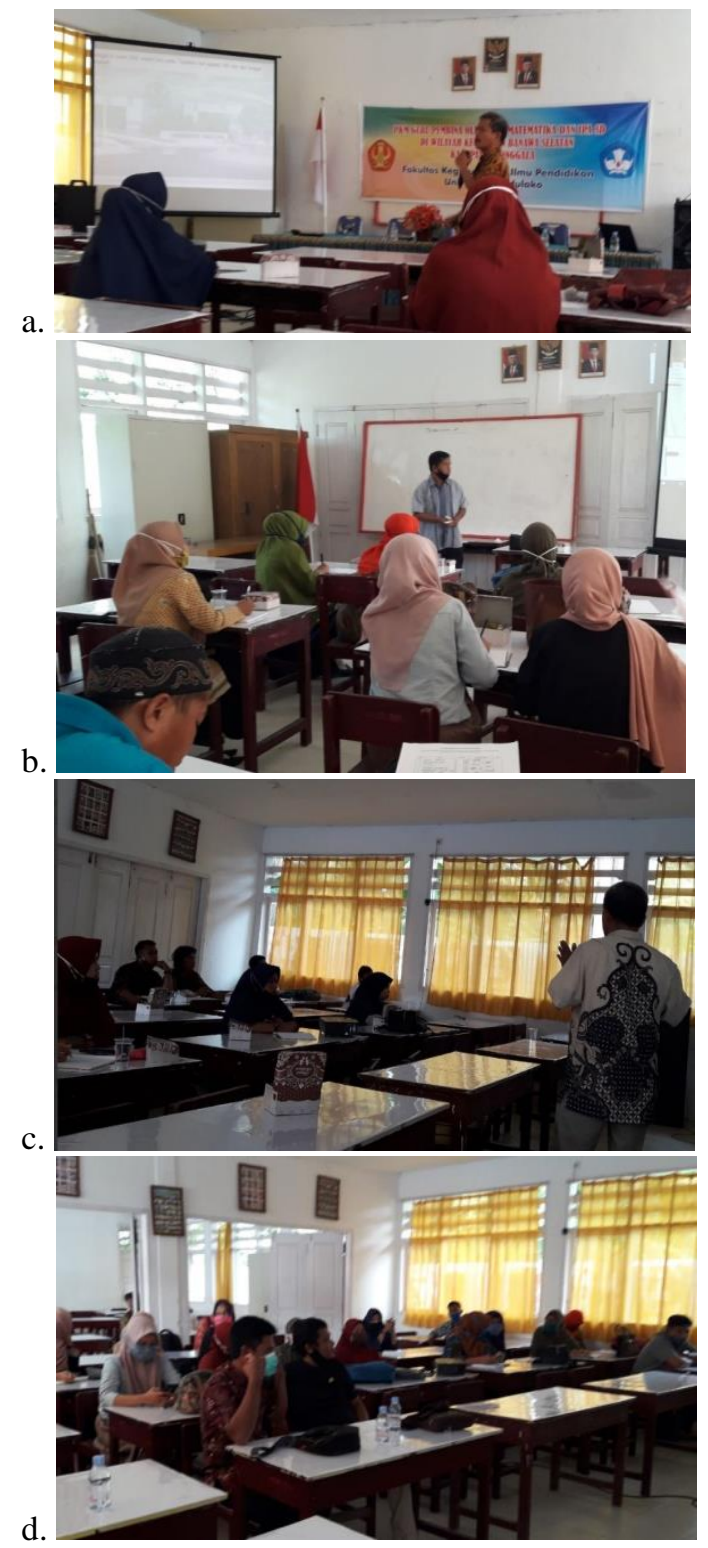

Gambar 4. Pelaksanaan pelatihan guru pembina olimpiade KKG wilayah Banawa selatan
Motivasi dan keingintahuan keingintahuan peserta KKG guru pembina olimpiade sains nasional bidang matematika dan IPA SD yang tinggi untuk dapat menyelesaikan soal-soal tiga tahun terakhir merupakan suatu faktor positif yang sangat mendukung terlaksananya kegiatan pengabdian ini. Motivasi yang tinggi tersebut juga mendukung tercapainya luaran yang direncanakan, minimal 5 orang anggota $\mathrm{KKG}$ wilayah gugus I Kecamatan Banawa Selatan dapat mengerjakan soal-soal olimpiade tingkat kota tahun 2019.

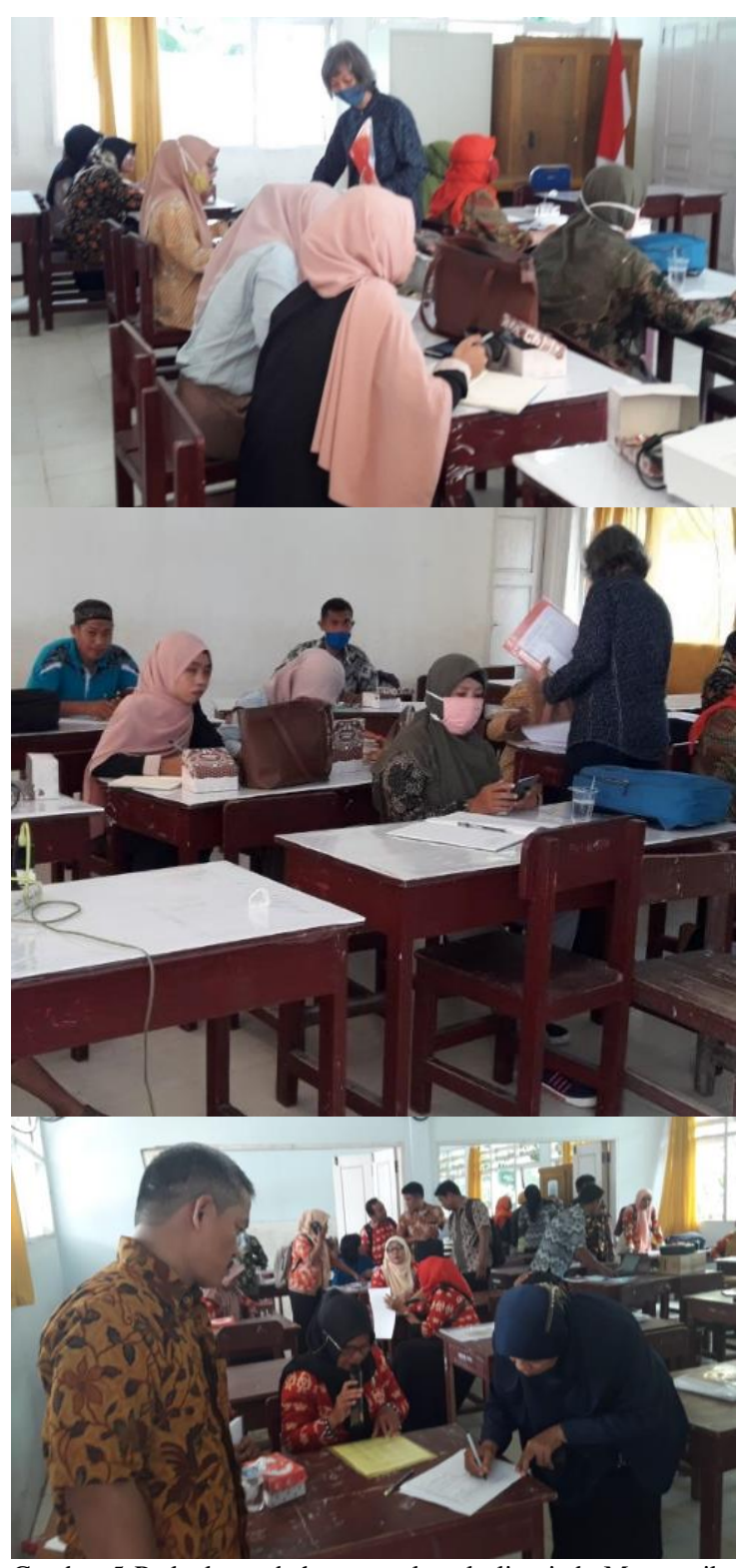

Gambar 5 Praktek pembahasan soal-soal olimpiade Matematika dan IPA didampingi Tim PKM 
Luaran yang telah dicapai, adalah minimal 5 orang anggota KKG wilayah gugus I Kecamatan Banawa Selatan dapat mengerjakan soal-soal olimpiade tingkat kota tahun 2019 dan pembahasan soal olimpiade hasil kerja kelompok guru-guru Pembina olimipade yang sementara proses pengetikan dan proses review untuk diterbitkan. Kegiatan PKM ini mampu memotivasi para guru untuk berkompetisi secara sehat dengan mengedepankan sportivitas guna mencapai prestasi terbaik. Dampak yang diharapkan dari program ini adalah meningkatnya kualitas pendidikan di daerah masing-masing yang pada gilirannya akan meningkatkan kualitas pendidikan nasional.

\section{KESIMPULAN}

Kegiatan PKM guru pembina olimpiade sains nasional SD bidang matematika dan IPA, telah terlaksana dengan baik. Mitra KKG wilayah gugus 1 kecamatan Banawa Selatan, memperoleh pemahaman konsep-konsep dasar matematika dan IPA yang penting dan sangat menunjang untuk mengikuti materi matematika dan IPA yang membutuhkan analisa yang lebih tinggi. Guru-guru yang tergabung dalam KKG juga telah mampu mengerjakan soal-soal Olimpiade Sains Nasional Sekolah Dasar (OSN-SD) bidang Matematika dan bidang IPA tiga tahun terakhir. Hasil pekerjaan mitra KKG tentang pembahasan soal-soal tiga tahun terakhir sementara proses pengetikan untuk dibuatkan buku referensi untuk menunjang kebutuhan pembinaan berkelanjutan khususnya di wilayah kecamatan Banawa Selatan.

\section{UCAPAN TERIMA KASIH}

Para penulis berterima kasih atas dukungan finansial dari DRPM Kemenristek DIKTI No: 091/SP2H/PPM/PRPM/2020, 16 Maret 2020.

\section{DAFTAR PUSTAKA}

[1] Dinas Pendidikan Kabupaten Donggala, 2018, Gambaran Olimpiade di Kabupaten Donggala

[2] Surat Keputusan Direktur Pembinaan Sekolah Dasar, Tahun 2016, 017 dan 2018, http://ditpsd.kemdikbud.go.id

[3] Direktorat Pembinaan Sekolah Dasar Direktorat Jenderal Pendidikan Dasar dan Menengah Kementerian Pendidikan dan Kebudayaan. (2019). Juklak Pelaksanaan Kompetesisi Sains Nasional Tingkat SD. Jakarta.

[4] Sukino. (2011). Maestro olimpiade matematika SD. Jakarta. Erlangga.

[5] Binatari Nikenasih, 2011, Olimpiade Matematika Tingkat Sekolah Dasar. Universitas Negeri Yogyakarta.

[6] Yuli Ardika P. (2019). Juara OSN Olimpiade Sains Nasional Matematika SD/MI. Surakarta: Lingkar Media.

[7] Hikmah Supriyati. (2018). Master OSN IPA $S D$. Sleman: C-Klik Media.

[8] Sanjaya, D., \& Wijaya, S. (2007). Strategi penyelesaian soal-soal matematika yang mengasyikan untuk SD/MI dan SMP/MTS. Jakarta: Kandel.

[9] Tampomas, H. (2006). Langkah cerdas menuju olimpiade matematika untuk SD dan MI. Jakarta: Grasindo.

[10] Tim Penulis Prestasi. (2013). Strategi Sukses Juara Olimpiade Sains IPA Tingkat SD. Semarang: Aneka Prestasi 
Jati Emas (Jurnal Aplikasi Teknik dan Pengabdian Masyarakat)

Vol. 4 No. 2 Oktober 2020 - e. ISSN: 2550-0821 